\title{
The Alignment of Interests of the "Private Sector" and the Citizens During a Transition Period in Transition Economies
}

\author{
James S. Ang ${ }^{1}$ and Elli Kraizberg ${ }^{*}, 2$ \\ ${ }^{I}$ Department of Finance, Barnett College of Business, Florida State University, Tallahassee, Florida 32306-1042, USA \\ ${ }^{2}$ Netanya Academic, 1 University St, Netanya, Israel
}

\begin{abstract}
The ownership of over 1600 firms in the Czechoslovak Socialist Republic has been transferred to the private sector in the early 90 's. Twelve years later, less than $5 \%$ of the firms are still public companies and it is estimated that the assets of over $90 \%$ of the firms have been stripped and sold to various operators [1-5]. When governments decided to privatize state owned enterprise and distribute shares to the citizens, it needs to solve two problems. The first is how to level the playing field for the disadvantaged citizens, who are less sophisticated and too diverse to organize against expropriation by others. The second is to obtain new financing for the privatized firms. We propose an original scheme in which the less sophisticated citizens make 'sidecar' investment along side the sophisticated, but with a right to redeem their shares. The scheme assures the citizens do not misallocate funds to less valuable firms, or pay more than what the sophisticated pay. It also align the interests of the citizens and the sophisticated investors such as investment funds.
\end{abstract}

Keywords: Distribution of state owned assets, private sector, alignment of interests.

\section{INTRODUCTION}

A well functioning financial market in transition economies is a key ingredient for a successful strengthening of the private sector, especially in countries where massive amount of wealth is being transferred to the private sector. Although the objective is to distribute ownership to the citizens, this is always never realized in practice. The citizens, who are seriously handicapped in knowledge and information, as well as ability to organize, are often expropriated by the sophisticated investors or those with control rights. This conflict of interest is well recognized. (see also Anderson and Makhija [6], Bekhaert [7], Boyco et al. [8, 9], Laffont et al. [10], Begg [11], Blanchard et al. [12], BosnerNeal et al. [13], Carlin et al. [14], Classens [15], Classens et al. [16], Fluck et al. [17], Frydman et al. [18], Hingorani et al. [19], Lopez-de-Silanes [20], Makhija et al. [21], Maskin [22], Pohl et al. [23], Shafic [24], Zijlstra [25]). However, as witnessed from the privatization experience of the Eastern European countries, the implemented privatization scheme, such as the voucher system, failed to protect the interests of the citizens. No privatization scheme could successfully protect the interests of the citizens unless there exists an efficient price discovery mechanism that enables the unsophisticated not to do worse than the sophisticated. At first glance, this is a seemingly untenable objective, as the sophisticated, with better access to information and ability to analyze, shall guarantee that they would choice better quality firms to invest, and /or better lower price. Our innovation consists of two essential elements. One, instead of attempting to solve the asymmetric information problem and equalize the citizens' information with that of the sophisticated, we propose that the citizens are allowed to invest along side the sophisticated at privatization, i.e., to free ride on the information of the sophisticated, to choose the same investments and pay the same

*Address correspondence to this author at the Netanya Academic, 1 University St, Netanya, Israel; E-mail: ekraizberg@yahoo.com price and yet without under the control of the sophisticated or pay a fee to them. Two, to minimize agency costs to the citizens from being expropriated by the sophisticated after privatization, we propose that the citizens be given higher priority in distribution, including a right to redeem shares. This relieves the demand that all citizens be as informed as the firm managers and large investment companies, as well as the need for the citizens to develop the analytical skills to evaluate investments.

We use the experience of the Czech Republic in the past 12 years as the back drop of our analysis (Kraizberg [1] Ang et al. [26]), however, our result is quite general and could be applicable to both transition and Western economies whenever privatization involves citizens participation. In the Czechoslovak Socialist Republic the ownership of over 1600 firms has been transferred in the early 90 's to the private sector. Twelve years later, only less than $5 \%$ of the firms remained as public companies, and it is estimated that the assets of over $90 \%$ of the firms have been stripped and sold to profit-motivated operators Kraizberg [1], ING Bank [2], Hospordaseke [3] Pistor et al. [4], Prague Post [5]. Similar experience has also been reported in other Eastern- European markets (See also Ludek [27], Vecernik [28], Sims [29], Filer [30], Svejnar [31]). Consequently, the transition to a healthy private sector is thwarted.

We propose a two stage process. In the first stage, we deal with the issue of raising fresh capital for the upcoming privatized firms. Sophisticated investors with funds are invited to bid on a set percentage of the firm, including the management right. The price set in the first stage by the sophisticated becomes the price (equivalent value in vouchers)to be paid by the unsophisticated citizens. The details of our scheme are discussed below.

\section{DEFINING THE ISSUE: EXPROPRIATION OF LAWFUL CITIZENS RIGHTS}

During the first stage of a transition in which State Owned Assets are reallocated, great majority of citizens simply lack the education, experience, and knowledge to acquire informa- 
tion, if available, in order to perform valuations of the assets made available for distributions.

Lacking this ability, they could not make intelligent choice as to whether to hold or sell assets distributed to them, or to choose and bid among assets offered. Unfortunately, entrusting citizens' rights to others often result in wholesale expropriation by well-endowed insiders (information and capitalwise).

Furthermore, in comparison to the insiders (factory managers, former politicians and bureaucrats, individuals with wealth or access to funds which manage these assets), citizens are handicapped in even more ways. First, the insiders have superior information about the value of the assets that they could use to their advantage. They could engage in winner picking, and leave non-viable assets to the average citizens. They could further tilt the playing field in their favor by releasing no information or false information. Moreover, States, with or without the assistance of outside consultants from developed economies, often opted for theoretically elegant schemes that are far too complicated for the citizens to make meaningful participations. For instance, auction has been well studied theoretically (see Boyco et al. [9]), Fluck et al. [17], Shafic [24], Jones et al. [32] and others cited already), and has shown to apply to bidding by sophisticated participants. They are not appropriate for small, fragmented uninformed citizens. Most of these citizens are from countries with no tradition in capital markets, and most citizens had no training or experience with valuing corporate assets that involve projections to many years into the future.

\section{THE SECOND STAGE OF THE TRANSITION: POST DISTRIBUTION}

At this stage, citizens now hold publicly traded shares of the previously state owned assets. They are, however, handicapped in several ways. First, each citizen does not own any share, or, a negligible share in a company, which means they have no voice, nor are they justified to invest time and energy to investigate and monitor these companies. Moreover, the citizens are too dispersed to be organized, say through organized funds that seek to protect the citizens' interests.

Consequently, citizens' interests have often little or no representation in these newly privatized firms. They could not exercise any form of effective governance. Worst is that the insiders, for all practical purpose, exercise unhampered total control of the enterprise. In many cases, citizens are expropriated by losing their shares with little or no compensation. This is manifested in several ways. Shares of many privatized firms that are too small to have a viable stock market with sufficient liquidity. They may eventually be delisted in spite of the fact that the firm's asset may be quite valuable. The shares of the citizens are rendered worthless, while the insiders could enjoy the returns of the assets or dispose them for cash. Some insiders just simply strip the assets piece by piece, or sell the assets wholesale. Other insiders may transfer citizens' assets to their own firms.

Summarizing the above, dispersed, unsophisticated citizens lack the ability to organize and to impose good governance, and more specifically, to monitor the actions of the insiders. Thus, citizens lose twice in the transition; first, at the distribution phase where their lack of knowledge, information and capital consigns them to own disproportionately greater shares of lemons i.e., companies of inferior quality, or even, worthless, and, in the second post distribution phase, to be deprived of their shares.

Moreover, many of the former state enterprises are often poorly run, many in disrepair, and lacking modern equipments and technology, infusion of new money is necessary for these enterprises to be viable. Any distribution scheme that does not provide for cash infusion from the birth of these new firms may only be a futile exercise in practice. Once again, average citizens will be left with holding the empty bag - the lemons that could not get later funding. Thus, any solution to protect the citizens' rights to these state assets must not only be fair, but must give assurances that they must be owning part of viable enterprises only.

\section{THE POTENTIAL SOLUTION: UNDERLYING PRINCIPLES}

We shall propose below a set of practical solutions that would protect the interests of the less sophisticated citizens and may assure infusion of badly needed capital and a viable private sector. These ideas are inspired by principles in financial security design, financial engineering, and corporate governance; many are our original ideas that are explained by the authors in details in a separate paper, which this essay is based on.

\subsection{General Principles}

Our first principle is that a solution should be simple, achievable and realistic. Specifically, we do not require nor suggest citizens to become more sophisticated by education, since this will require a full-scale analysis that includes the huge amount of investment needed, or that, insiders should be taught not to become self-interested, which would be against human nature.

We also require that the specific solution should be implementable. The uniqueness of the solution lies in how various components are put together, while each component must be off the shelves, i.e., well tested in the real world.

Citizens, being the least informed, should not be asked to do things they of which have no comparative advantage if not severely handicapped. These are: a) collecting financial and market data for many companies, b) making calculations and comparison of firm values, c) spend time, d) energy to monitor managers of many companies, and e) taking large unknown risks. Incumbents (factory managers, policy makers, and any well-endowed participant) need not be given the mandate to manage the firm automatically, unless, they could themselves worthy, as they are often the source and beneficiary of expropriating the citizens.

\subsection{Protecting the Citizens}

A sensible strategy is for the small and unsophisticated citizens to 'free ride' with the well-endowed insiders. Specifically, citizens should be given the opportunity to invest along side the insiders. This is what is known as 'sidecar' investing that should be differentiated from investing in the funds of the sophisticated. In the latter, citizens invest capital, rights or allocated vouchers with investment companies and their professional managers. In 'sidecar' investing, citizens are allowed to emulate whatever the large funds invest at exactly the same 
terms or better, free of any charge, since they are not under the direct management of the funds.

In practice, government could simply set aside a certain portion of all or some privatized securities for 'sidecar' investment by the citizens. For instance, government could set aside one-third of a certain security to be placed by a newly privatized company for citizens, in which they would receive the same interests and protection negotiated or bid by the sophisticated investment companies on the other two-third. Here, the sophisticated large investment funds spend resources to identify which company to invest, and at what terms, citizens are spared these expenses and thus free ride by taking up the one-third set aside after the funds make their bids and pay for them at the negotiated or bid price. Operationally, we visualize a two-stage process or at least two rounds of bidding for securities of the privatized firms.

In the first round, the sophisticated - investment companies, insiders, 'qualified investors' (i.e., high net worth) bid for a pre-determined portion of the securities offered. This round of bidding among the informed provides the necessary price discovery mechanism. It is set by competing sophisticated investors, and thus, gives the best pricing of the securities given the information available to them. By excluding the uninformed from this round, mispricing and expropriation would also be minimized.

In the second round, having the price and terms fixed by the sophisticated investors in the first round, the less informed citizens need only to choose firms and securities to invest their funds based on their personal preferences, attitudes toward risk taking, or familiarity bias, to invest their capital, rights, or voucher points. They are relieved of determining values, which they are ill equipped, and yet be assured that they are not doing worse than the sophisticated, as both the sophisticated investors and citizens pay the same price/resources for the same security or asset.

The above solves the pricing problem in the first phase of the transition, however, in the post transition phase, the average citizens are still exposed to the risks of unfavorable fortune and thus value of these enterprises could decline. Thus, they would need additional safeguards. In order to reduce citizens' exposure to risks, as they may not have the investment companies' ability to hedge or make timely trades, we further propose that citizens need to be given securities that are of higher priority in distribution and liquidation than that held by the institutions. Our proposal to give protection to the citizens' interests and yet not requiring them to be well informed is to place them in front of the line when it comes to distribute funds from the company. Specifically, debt instruments with higher priority in liquidation, or higher priority equity such as stocks with a put option for the citizen to present to the company and redeem for cash, and a call option to ride on the firm success. This arrangement is similar to a convertible debt, in addition to a protection against expropriation. In other words, the citizens benefit both way, when the firm excels and when the firm's prospect should turn bleak. If the firm could not redeem due to lack of cash, the citizens would still be ahead of the line in liquidation. Thus, no matter how much better informed the large sophisticated investors are, the smaller, less informed citizens would be paid first in the second post distribution phase. It should be pointed out that the citizens are compensated for being handicapped even in the first phase.
This is because they are paying the same price on the same security as the large sophisticated investors in the first round with an added bonus - the option to redeem. This is a valuable option, in essence a protection, in which they do not have to pay.

Summarizing the above, citizens not only save on information, transactions, and decision making costs; they are also prevented from making bad decisions or to buy the lemons that the sophisticated choose not to own. Unlike the less sophisticated citizens, the investment companies would refrain from bidding on worthless companies, and pay little for low value assets. Additionally, their higher priority helps them to level the playing field against more nibble investment companies and prevent the sophisticated getting paid before the citizens do.

\subsection{Good Governance}

A major contributing factor that enables the insiders to expropriate the citizens in the post distribution transition period is a lack of good governance. Our approach to good governance is also grounded on practical considerations. Citizens need good governance to protect their interests, and yet they are ill equipped to perform the task. In addition to lacking sophistication, experience, they also lack capital at stake in a firm to warrant spending the type of effort and time required to do the job. Furthermore, they are usually not easy to get organized and to achieve economies in monitoring, and in having large voting blocs for effective deterrent. The standard good governance practice that relies on alignment of interests between the insiders and the investors has been proven again and again not capable of working. This is because the convergences of weak court protection for citizens' economic interests, nascent capital markets with weak protection for small investors, and insiders, who were former factory managers and/or politically connected, have strong self interests that allow them to show little regard for the rights of the small shareholders. They dominate the board, and thus, remove the only 'nominal' representation the citizens have. When facing expropriation by the insiders, the citizens have little recourse through capital markets, especially when the firm's stock trading is too thin to reflect true value, and is too low when insiders' private benefit of control is discounted. They would have low likelihood of success in seeking remedy through the inefficient and sluggish court system.

Since the consequence of poor governance is especially acute in a transition economy, where the opportunity for grabbing massive wealth is unusually apparent, solution to the "Agency problem" (self-interest behavior) must attack its root causes. The first is that the control right to run the firm need not be handed to the incumbent managers or their backers. They may or may not be competent but based on the experience learned from the previous privatizations, such as in Eastern Europe, had shown them to be the major participants and beneficiaries in the expropriation of the citizens.

There are several ways to limit the participation of the incumbent managers and to obtain good governance:

(i) Consolidate all smaller business units into larger entities with more scrutinized management team. Consolidations have other benefits for the citizens: a larger firm makes a more liquid market for the firm's stocks, there would be greater production of information, more 
demand and participation by large investors, and they would be more visible and thus more transparent. Most of all, larger firms remove a technique that incumbent managers of smaller firms could use to expropriate citizens; voluntarily delisting stocks from trading. Citizens holding shares of these no longer traded stocks would find them worthless, especially when the companies cease to release any information.

(ii) Recognize that there could be several unrelated teams competing to manage the firm. By allowing the right to manage the firm be an object of auction, incumbent managers, many are of inferior quality, who fail to secure financial supporters would not even be able to participate in the bidding process. In order to ensure the prices, various competing teams bid, which reflect their ability to create values but not for what they could extract as private benefits of control, therefore there is need to add safeguards to the bidding process. This can be obtained by a 'check and balance mechanism' built into the bidding process of the first stage. For instance, for a block of securities that is privatized, after deducting, say, one-third set aside for citizens, the bidding could be designed in such a way that there would be at least 2-3 investor groups controlling significant shares and have representations on the board. For instance, the bidding process could set aside a block of $15 \%$ (for management right), and three equal size blocks of $10 \%$, $10 \%$, and $10 \%$ to unrelated investor groups that together could thwart the controlling group's self interested behavior, or even remove the managers. The remaining $25 \%$ is available for by 'qualified' investors and institutions (sophisticated and high net worth). They form the basis of stocks for trading, or floats. Thus, the sum of the three non-management blocks is $30 \%$, which is twice the voting power of the managing group, and possibly large enough to change management. Even in the scenario that the managing group "bribes" one of the $10 \%$ block to defect, the remaining $20 \%$ plus $25 \%$ of votes to various sophisticated investors and with some support from the $30 \%$ citizen investors may also create effective deterrents.

(iii) Recognize that agency problems driven by poor governance that could come from many sources, that is, a multi level strategy is often needed. Given this intuition citizens in these transition economies face today: (a) sophisticated insiders, (b) outside well endowed investors, (c) a developing capital markets that is relatively thin in trading and incomplete in regulations, (d) increasing demand to adapt to international accounting standard. On the other hand, today's situation differs from that of a few years by appearing to be more open and dynamic, the motivations that the informed and the insiders have to expropriate the citizens are just as great. Our recommendation for better governance is to incorporate these realities in a multi prong approach, such as, collectively monitoring the firm nowadays via the Internet. This means that better governance requires not only greater transparency, but also allow the firms to make the disclosed information in a format that is accessible by the investors electronically.

In summary, external market for corporate control, as a means for good governance, could complement internal govern- ance, but more importantly, it could substitute for poor internal governance by outside investors removing the incumbent management team. In some countries, much of the expropriations of the citizens by the insiders are done at the factory floor level. Monitoring by conscientious independent board members is of little use, since board members have little access to factory floor information, and the worse is that the incumbent managers are the ones to provide the information. Thus, effective governance requires eyes and ears at the factory floor.

\subsection{The Role of Investment Companies}

We have discussed the need to have large outside investors with funds and expertise to either manage or monitor, and yet, let the citizens to free ride on their effort. In previous privatizations, there were participations by investment companies or funds. However, they are to be distinguished from the ones we have in mind. These older versions of investment companies were vehicles to expropriate the unsophisticated citizens under the guise of providing citizens diversification and expertise. In the process, they gained control of the assets without putting up money of their own. Even for the legitimate investment companies, high management fees could consume a significant portion of the citizens' stake. More critically, they did not provide one of the most important needs of the newly privatized firms - fresh capitals to modernize plant, make acquisitions, etc.

In contrast, the investment companies we visualize are those that have had a good record of investing funds, i.e., requiring established reputation to eliminate the participation of 'flight by night' funds. We further stipulate that they commit a significant amount of their own funds into the firm. Since the citizens' free ride is on their expertise in project selection and pricing, they do not directly deal with the citizens, collect fees, or have the opportunity to expropriate citizens' funds. Their incentive to invest arise from the fact that because only the sophisticated investors could participate in the first round competitive bidding, even the eventual highest price bidder must factor in at least a satisfactory returns, given the expected circumstances and resulting risks.

Finally, we consider situations when the country could initially attract less reputable type of institutional investors. In the worst case all outside investment companies have their own agenda, i.e., taking care of their own investors and not the citizens', then a solution is required that these funds allow the citizens to invest with the parents of these funds, and not to the local subsidiary, formed to hold local assets. The reason is that the victims of expropriating actions by these funds would be the citizens invested in their local subsidiaries, and the beneficiaries are the investors in the fund's parent company. Thus, allowing the citizen of one country to invest in the parent of the fund would also reduce the citizens' personal risks by providing them a more internationally diversified portfolio, that is, "if you can't beat them, join them" plan.

\section{SUMMARY AND CONCLUSIONS}

This essay raises an issue: what is the purpose of privatization and the establishment of a private sector if the end result is that the vast majority of State Owned Assets are rendered worthless or end up in the hands of few, while the broad group of Citizens are deprived of justifiable property rights and lose interest in the formation of a Viable private sector? 
There has been enough recent experience that, in spite of the praise for the success of larger privatized firms, most of the smaller and medium size privatizations have been more successful at expropriating the citizens. Average citizens are severely handicapped as independent investors vis a vis the sophisticated and insiders, our recommended solutions realistically do not ask for citizens' active involvement.

Our approach is that those in charge of designing the privatization schemes and transition period afterwards should provide citizens with some specific advantages in order to offset their handicaps. Specifically, we recommend that sophisticated investors with their own funds be allowed to engage in the first round bidding of the privatized firms. This stage provides a rational price discovery mechanism as the price is determined by only the sophisticated investors. The process also allows injection of fresh capital from these sophisticated funds and other 'qualified' investors. Furthermore, unless incumbent managers could find support from a fund that wins the right to manage in the first round, new managers could replace them, thus, removing one source of entrenched interest that often benefited from 'grabbing' public properties. Having the sophisticated set the terms of the securities, bonds and stocks as well as hybrid combinations, the unsophisticated citizens would pay the price set in the first round. They may choose which securities, and which firms to invest or allocate their vouchers from the portion of the total securities set-aside for them. The extra boost the citizens receive is that although they pay the same price as the sophisticated, their securities have an added feature for their protection - they have the option to demand early redemption to allow them to be first in line in distribution and in liquidation. In summary, our original proposal is to allow the uninformed citizens to free ride with the sophisticated and insiders as in a 'sidecar' investment, but without paying various fees to the investment companies.

Because expropriation of the citizens is a result of not having good governance in these newly privatized firms, we devote considerable thoughts on the ways through which the governance could be improved. We understand that realistically, effective governance would have to be directed at several levels. By introducing outside investment companies committing significant own funds, we have self-motivated large investors conducting broad monitoring. Citizens can also free ride on their monitoring effort. We ask for investment funds that have established reputation and could provide their own funds. The role of transparency in fostering good governance is acknowledged by emphasizing on the adaptation of the higher international accounting standard, and by disclosing firm information frequently and timely via the Internet.

\section{REFERENCES}

[1] Kraizberg E. The Mass privatization process in the Czech Republic. Eur Financ Rev 1999; 3: 175-203.

[2] ING Bank. Research Reports. Emerging Markets Meltdown 1995.

[3] Hospordaske. Daily Newspaper Published in Prague 1995-2000.

[4] Pistor K, Spicer A. 1977 Investment Funds in Mass Privatization: Lessons from Russia and the Czech Republic. World Bank Group
Note Number 110, 1977. http://www.worldbank.org/ html/fpd/notes/110/110summary.html

[5] Prague Post. Weekly Newspaper Publish in Prague 1995-2000.

[6] Anderson CW, Makhija AK, Spiro MH. Foreign Ownership in the Privatization Process: Empirical Evidence form Czech Privatization. Working Paper. University of Pittsburgh 1997.

[7] Bekaert G. Market integration and investment barriers in emerging equity markets. World Bank Econ Rev 1995; 9: 75-107.

[8] Boycko M, Shleifer A, Vishny R. Voucher privatization. J Financ Econ 1994; 35: 249-66.

[9] Boycko M, Shleifer A, Vishny RW. A theory of privatisation. Econ J 1996; 106: 309-19.

[10] Laffont JJ, Tirole J. Privatization and incentives. J Law Econ Organ 1993; 7: 84-105.

[11] Begg D. Economic reforms in Czechoslovakia: should we believe in Santa Claus? Econ Polit 1991; 12: 243-86.

[12] Blanchard OJ, Dornbusch R, Krugman PR, Layard R, Summers LH. Reforms in Eastern Europe: MIT Press 1991.

[13] Bosner-Neal C, Brauer G, Neal R, Wheatley S. International investment restrictions closed-end county fund prices. J Financ 1990; 45: 523-48.

[14] Carlin W, Mayer C. Restricting enterprises in Eastern Europe. Econ Policy 1997; 13(2): 77-105.

[15] Claessens S. Corporate governance and equity prices: evidence from the Czech and Slovak Republics. J Finance 1997; 52: 164158 .

[16] Claessens S, Djankov S, Pohl G. Ownership and Corporate Governance: Evidence form the Czech Republic Working Paper. World Bank: Washington DC. Policy Research Paper No. 1737; 1997.

[17] Fluck S, John K, Ravid A. Privatization with Political Constrains: Auctions Versus Private Negotiations. Working Paper: Stern School of Business 1995.

[18] Frydman R, Gray CW, Hessel M, Rapaczynski A. When does Privatization Work? The Impact of Private Ownership on Corporate Performance in Transition Economies Working Paper, C.V. Starr Center for Applied Economics. New York University: New York 1998.

[19] Hingorani A, Lehn K, Makhija AK. Investor behavior in mass privatization: the case of the Czech voucher scheme. J Financ Econ 1997; 44: 349-96.

[20] Lopez-de-Silanes F. Determinants of privatization prices. Q J Econ 1997; 112: 965-1025.

[21] Makhija AK, Patton JM. The Impact of Firm Ownership Structure on Voluntary Disclosure: Empirical Evidence from Czech Annual Reports. Working Papers: University of Pittsburgh 1997.

[22] Maskin E. Auctions and Privatization Mimeo. Harvard University 1991

[23] Pohl G, Anderson RE, Claessens S, Djankov S. Privatization and Restructuring in Central and Eastern Europe: Evidence and Policy Options, Working Papers, World Bank: Washington DC, Technical Paper No. 368, 1997.

[24] Shafik N. Making a market: mass privatization in the Czech and Slovak Republics. World Dev 1995; 23: 1143-56.

[25] Zijlstra K. Czech Republic: A Case Model. Special Report 1995.

[26] Ang J, Kraizberg E. The voucher privatization process - Ex Post, Working Papers 2003.

[27] Luděk U. Testimony of economic thought under normalization. Econ Paper Prague 2002; 11: 87-9.

[28] Večerník J, Matějů P, Eds. Ten Years of Rebuilding Capitalism, Czech Society after 1998. Prague: Academia 2000.

[29] Sims L. Big-Bang vs. Gradualism: The Czech Republic versus Hungary EU Center of California Undergraduate Conference 2008.

[30] Filer R, Hanousek J. Data watch: research data from transition economies. J Polit Perspect 2002; 16: 225-40.

[31] Svejnar J. Transition economies: performance and challenges. J Polit Perspect 2002; 16: 3-28.

[32] Jones SL, Megginson WL, Nash RC, Netter JM. Share issue privatizations as financial means to political and economic ends. J Financ Econ 1999; 53: 217-53. 